\title{
Elephants or Excrement? Comparison of the Power of Two Survey Methods for Elephants in West African Savanna
}

\author{
Emmanuel M. HEMA ${ }^{1}$, Richard F. W. BARNES ${ }^{2}$ \& Wendengoudi GUENDA ${ }^{1}$ \\ ${ }^{1}$ Université de Ouagadougou, UFR/SVT, laboratoire de Biologie et Ecologie Animales, Burkina Faso \\ ${ }^{2}$ Center for Community Health, Division of Academic General Pediatrics, University of California at San Diego, \\ La Jolla, CA 92093-0927, USA \\ Correspondance: Emmanuel M. HEMA, Université de Ouagadougou, UFR/SVT, laboratoire de Biologie et \\ Ecologie Animales, 09 B.P. 848 Ouagadougou 09, Burkina Faso. E-mail: hema.emmanuel@yahoo.fr
}

Received: October 24, 2012 Accepted: December 20, 2012 Online Published: March 7, 2013

doi:10.5539/ep.v2n2p14 URL: http://dx.doi.org/10.5539/ep.v2n2p14

\begin{abstract}
Statistical power is the key issue when evaluating wildlife trends. Wildlife managers in West Africa lack light aeroplanes and must often estimate wildlife trends on foot, either by counting the animals themselves or by counting their dung. We compared direct ground counts of elephants and dung counts in two consecutive years in Nazinga Game Ranch in southern Burkina Faso, an area of savanna woodland and shrub savanna. Our purpose was to determine which method was most likely to detect a trend in elephant numbers. The direct ground counts each covered $680 \mathrm{~km}$ of transect but sightings were too few to give good estimates of elephant numbers. The dung counts each covered $54 \mathrm{~km}$ of transect recorded very large numbers of dung-piles and returned estimates with smaller coefficients of variation. Consequently dung counts had greater statistical power for detecting trends. Although dung counts have been mostly applied in forests, they should also be used in open habitats where information on long-term trends is sought.
\end{abstract}

Keywords: elephant, survey, dung, Burkina Faso, faecal count

\section{Introduction}

Management of wildlife populations requires estimates of population size and trends. The key issue in detecting trends is statistical power: the probability that a change in numbers will be detected, or, more formally, the probability that the null hypothesis will be rejected when it is false (Taylor \& Gerrodette, 1993). Maximum power can often be achieved by increasing sample size, but that is expensive and most wildlife managers operate under severe budgetary constraints. The challenge for the wildlife manager is to find a method that, when used regularly, balances cost with power. Here we compare two methods in the Nazinga Game Ranch, in the West African savanna, for monitoring elephant trends.

Large mammal populations in West Africa are often at low density. Frequently animals are scattered or live in groups that vary in size. They are difficult to see in the field because of their coat color and behavior (Jachmann, 2001). Furthermore, visibility is poor in thick vegetation such as savanna woodland. With direct ground counts, one often sees no animals in many transects, while a few transects record many sightings. These features of herbivore biology and dispersion mean that direct ground counts produce estimates with large variances and wide confidence limits (Jachmann, 1991; Barnes, 2002). The same is true of many aerial sample counts. When counting sparse elephant populations $\left(<0.5 \mathrm{~km}^{-2}\right)$, aerial sample counts have poor detection efficiency and return inaccurate estimates with low precision (Bouché, Lejeune, \& Vermeulen, 2012). Such estimates lack the statistical power to detect changes in numbers (Taylor \& Gerrodette, 1993).

Light aeroplanes are much less common in West Africa than elsewhere on the continent. In addition, aviation fuel is not readily available in most protected areas and flying is often restricted because of security considerations. Consequently aerial surveys, whether total or sample counts, are more difficult and expensive to arrange than in eastern or southern Africa. Therefore wildlife managers in West Africa are often obliged to count animals while walking along transects ("direct ground counts"). A case in point is the Nazinga Game Ranch, in the savanna zone of southern Burkina Faso. Over the years numerous counts of elephants, using different methods, have been conducted. But the large variations between counts, even between counts with similar 
methods, mean that managers have no clear idea of the trend in elephant numbers. There is a need for a counting method that is cheap, easy for the park staff to conduct once a year and that will provide consistent estimates to reveal trends in the elephant population.

Large herbivores produce large quantities of dung. Dung-piles, whether of elephants, Loxodonta africana, or antelopes, are more abundant and most likely to be detected and counted than the animals that produced them. Yet, until now, with a few notable exceptions (Jachmann, 1991, 2001; Jachmann \& Bell, 1979, 1984), many people still have the impression that they should only be used when the animals cannot be seen, for example in dense forests. This despite the fact that the reliability of dropping counts to estimate animal numbers has been well documented (Neff, 1968; Jachmann \& Bell, 1984; Johnson \& Jarman, 1987; Jachmann, 1991; Barnes, 2001; Karels, Koppel, \& Hik, 2004). A review of published accounts of dung counts of vertebrates raging in size from lizards to elephants showed that they gave estimates of animal numbers similar to those from other methods (Barnes, 2001). Dung counts give estimates that are as accurate and precise, or more precise, that aerial sample surveys (Barnes, 2001, 2002).

In this paper we compare direct ground counts and dung counts in order to determine the method with the greater statistical power for detecting trends in elephant numbers in a West African savanna.

\section{Study Site}

The Nazinga Game Ranch lies in southern Burkina Faso and covers about $975 \mathrm{~km}^{2}$ (Figure 1). The area is relatively flat with a mean altitude of $300 \mathrm{~m}$ (Spinage, 1984). It is traversed by the valley of the Sissili River and two of its tributaries, all of which flow seasonally. There is a single dry season from October to May and a rainy season from June to September. The mean annual rainfall is about $900 \mathrm{~mm}$. The vegetation is characterized by tall grasses, trees and shrubs with the main vegetation types being riverine forest, savanna woodlands and shrub savanna (Guinko, 1985).

\section{Methods}

\subsection{Elephant Counts 1982-2008}

Since 1982 numerous estimates of elephants have been made. However different methods have been used: aerial sample count (one count only), aerial total counts, direct counts on the ground and dropping counts. Since 1985 an annual direct ground count of all large mammals has been made in the dry season using the line-transect method.

\subsection{Direct Ground Counts in 2007 and 2008}

As part of the programme of annual direct ground counts, we made direct counts on foot in February 2007 and 2008 to estimate elephant abundance. The team followed the methods and used the same transects prescribed for the ranch's regular annual counts: 34 north-south transects that spanned the whole study area. The line transect survey method was used (Buckland, Anderson, Burnham, \& Laake, 1993; Buckland, Anderson, Burnham, Laake, Borchers, \& Thomas, 2001). The survey team consisted of three people who walked in a straight line on a pre-determined compass bearing. The team walked slowly and stopped each time an elephant group was seen. The number of elephants, the group's compass bearing and the distance from the transect to the center of the group was recorded. Later the perpendicular distance of the group from the transect centre-line was calculated. The DISTANCE 4.1.2 software package was used to estimate the number of elephants from the perpendicular distance and group size data (Thomas et al., 2003, 2010). 


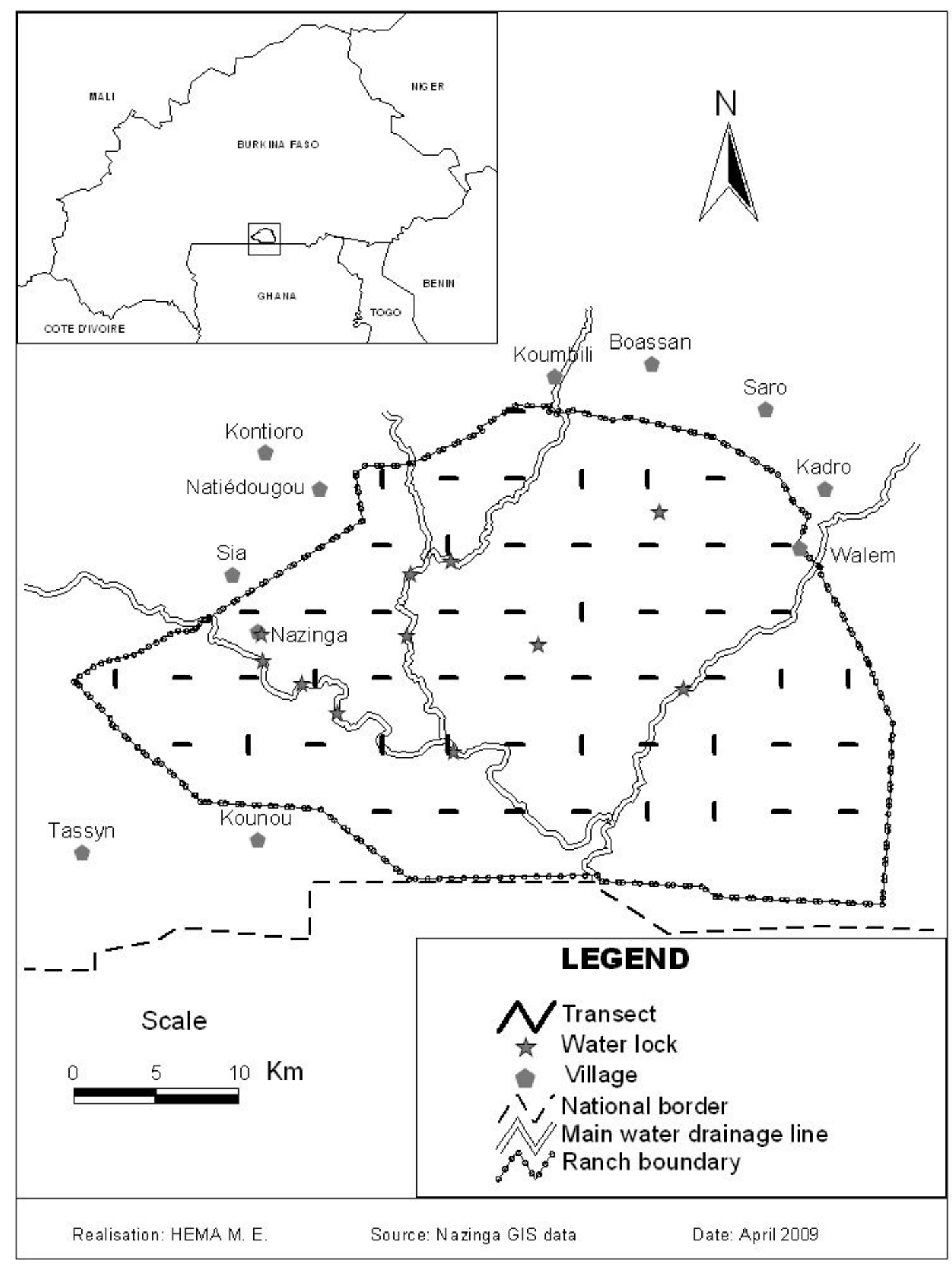

Figure 1. Map of Burkina Faso showing the location of Nazinga Game Ranch

\subsection{Dung Counts}

The dung-pile population is related to the animal population by the following formula (Laing, Buckland, Burn, Lambie, \& Amphlett, 2003):

$$
\widehat{D}_{a}=\widehat{D}_{s} /(\hat{p} . \hat{t})
$$

Where $\widehat{D}_{a}$ is the estimated density of animal signs in the study area, $\widehat{D}_{s}$ is the estimated animal's dung-pile density; $\hat{t}$ is the estimated mean time to decay of the animal signs present when the survey to estimate sign density is conducted, and $\hat{p}$ is the estimated rate of production of signs per animal during the period preceding 
the survey.

For a given animal population of a specific area, $\hat{t}$ and $\hat{p}$ are influenced by many environmental factors including seasonal variations (rainfall, temperature, termites activities), diet, animals' physiology and ages, size of dung, etc. However, if successive surveys are conducted at the same time of year, that is, $\hat{t}$ and $\hat{p}$ are constant from year to year, then equation 1 could be written as:

$$
\widehat{D}_{a}=c \cdot \widehat{D}_{s}
$$

Where $c$ is a constant $=1 /(\hat{p} . \hat{t})$.

According to this model, the trend in dung-pile density $\widehat{D}_{s}$ will reflect changes in the animal population's density $\widehat{D}_{a}$.

In a tropical site with one wet season and one dry season each year, all dung-piles decay rapidly during the wet season as a consequence of the heavy rainstorms and high temperatures (Jachmann \& Bell, 1979, 1984). During the dry season dung-piles dry out quickly and the decay rate is minimal and so dung-piles accumulate during the dry season (Jachmann \& Bell, 1979, 1984). Our dung counts were conducted in April-May (the peak of the dry season) in 2007 and 2008, so $\widehat{D}_{s}$ is an estimate of the density of accumulated dung during the dry season.

We used the method now widely adopted for evaluating the abundance of elephant dung (Hedges \& Lawson, 2006). The transect design differed from the direct counts. A grid of sides $2 \mathrm{~km}$ was placed over the study area. Then from a random start 54 transects were laid at $4 \mathrm{~km}$ intervals, such that each ran through the center of a selected cell (i.e, every other cell). Each transect was $1 \mathrm{~km}$ long and oriented north-south or east-west so as to cut across the drainage lines (Figure 1). The spacing of the transects ensured that they were not spatially correlated (Hema, Barnes, \& Guenda, 2010). This design was used for both dung counts.

The line transect survey method was used to estimate dung pile abundance (Barnes, 1993; Buckland et al., 1993). The survey team consisted of three people who walked in a straight line on a pre-determined compass bearing. The following notes were made for each dung-pile: distance along transect, the stage of decomposition and the perpendicular distance, measured with a tape, from the transect centre-line. Only those dung-piles that fell in the decomposition stages A to D defined by Barnes and Jensen (1987) were included in the analysis. Estimates of dung-pile abundance were obtained using the DISTANCE 4.1.2 software package (Thomas et al., 2003, 2010).

\subsection{Comparison of Estimates}

Estimates were compared using Norton-Griffiths $(1978) d$-test:

$$
d=\left(Y_{2}-Y_{1}\right) / \sqrt{\left(\operatorname{var} Y_{2}+\operatorname{var} Y_{1}\right)}
$$

Where $Y_{1}$ and $Y_{2}$ were the first and second estimates respectively, and $\operatorname{var} Y_{l}$ and $\operatorname{var} Y_{2}$ were their variances.

\subsection{Power Calculation}

We used the free software TRENDS (Gerrodette, 1993) to calculate the power of each method to detect a trend. This software allows the user to choose one out of several options for each parameter. We set an exponential decline of $10 \%$ per annum. We chose an exponential decline, rather than the type whereby the population decreases by the same number each year, because Caro (2008) fitted straight lines to log plots of population size, indicating exponential declines, for a wide range of large mammals. We set the CV to be that estimated for the 2007 counts. The CV was set to be inversely proportional to $\sqrt{ } N$ (Gerrodette, 1987), since with small elephant populations the variance tends to increase as populations decline (Barnes, 2002). The test was one-tailed, since a manager usually has anecdotal information indicating which way his population is trending. We set $\alpha$ (the probability of a Type I error) to 0.05 .

\section{Results}

\subsection{Elephant Counts 1982-2008}

Since 1982 the estimates of elephant numbers show considerable variation, even between estimates using the same methods in the same year, as in 1985 (Figure 2).

Only 21 elephant groups were seen in the 2004 direct count, and only 22 in the 2006 count; these sightings were too few to justify calculating an estimate and are not shown in Figure 2. 


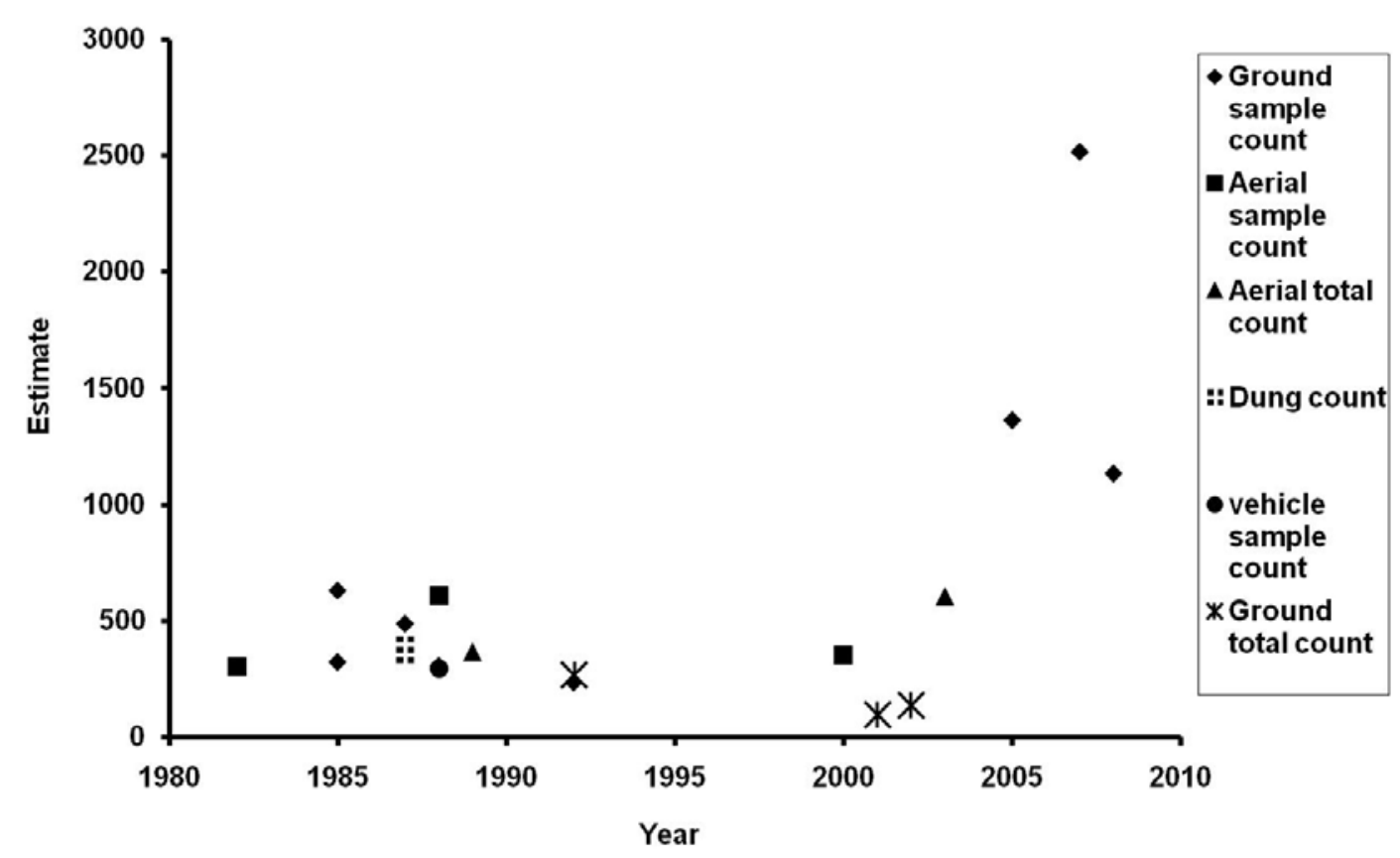

Figure 2. Estimates of elephant numbers in Nazinga Game Ranch from all types of survey from 1982 to 2008

Confidence intervals have been omitted for clarity. Additional data were collected from C. Lungren (pers. comm.); Bousquet (1982) in Jachmann (1988); O'Donoghue (1985); Jachmann (1988, 1991); Damiba and Ables (1994); Cornelis (2000); Ouédraogo et al. (2009); Bouché, Lungren, and Hien (2004); Hema, Ouédraogo, Belemsobgo, and Guenda (2007).

\subsection{Direct Ground Counts in 2007 and 2008}

The survey teams covered a total transect length of $680.2 \mathrm{~km}$ for each count. Forty-six elephant groups were seen in 2007 (Table 1). The median group size was 5 (mean $=7.4)$. The elephant population estimate was 2518 (95\% confidence interval: $1476-4294)$ or 2.57 elephants. $\mathrm{km}^{-2}$ (95\% confidence interval: $\left.1.51-4.38\right)$. This figure was considerably higher than any preceding estimate (Figure 2). The CV was $27.5 \%$.

The histogram of perpendicular distances for 2007 shows that fewer elephants were seen close to the transect's centre-line than in the 25-49 metre class (Figure 3).

The following year only 27 elephant groups were seen on the same transects (Table 1). The median group size was $4($ mean $=5.9)$. The elephant population estimate was $1134(95 \%$ confidence interval: $503-2553)$ or 1.16 elephants. $\mathrm{km}^{-2}$ (95\% confidence interval: $\left.0.51-2.60\right)$. The CV was $42.0 \%$.

While the 2008 count represented an apparent decrease of 55\% compared to 2007, the difference was not significant $(d=-1.64, \mathrm{NS})$.

Comparison of the earlier direct counts and the most recent direct counts suggests an increase (Figure 2): the three counts in 1985 and 1987 gave a median estimate of 487 elephants compared to a median of 1363 elephants for the three most recent ones in 2005, 2007 and 2008. 
Table 1. Estimates of the size of the elephant population in two consecutive years in Nazinga Game ranch. The data were collected by direct observations on the ground using the line transect method (Buckland et al., 1993; Thomas et al., 2003, 2010)

\begin{tabular}{lll}
\hline Parameter & $\begin{array}{l}\text { Elephant } \\
\text { population }\end{array}$ & Elephant population \\
& 2007 & 2008 \\
\hline Number of observations $(n)$ & 46 & 27 \\
Estimator & Uniform/Cosine & Half-normal/cosine \\
Number of parameters used in the estimate & 1 & 1 \\
$f(O)$ & 0.010227 & 0.0098603 \\
var $f(O)]$ & $1.42 \times 10^{-6}$ & $4.32 \times 10^{-6}$ \\
Effective strip width $w$ (in metre) & 97.78 & 101.42 \\
Densityestimate per km ${ }^{2}(D)$ & 2.57 & 1.16 \\
Var $(D)$ & 0.50 & 0.24 \\
$95 \%$ Upper confidence limit & 4.38 & 2.60 \\
$95 \%$ Lower confidence limit & 1.51 & 0.51 \\
$\%$ CV & 27.51 & 42.04 \\
Population estimate $(N)$ & 2518 & 1134 \\
$95 \%$ Upper confidence limit & 4294 & 2553 \\
$95 \%$ Lower confidence limit & 1476 & 503 \\
$X^{2}$ & 4.76 & 2.24 \\
$p$ & 0.783 & 0.134 \\
$d f$ & 8 & 1 \\
Range of observed group sizes & $1-27$ & $1-18$ \\
Density of groups estimate $\left(\right.$ in $\left.\mathrm{km}^{2}\right)$ & 0.35 & 0.20 \\
Mean group size estimate $(E(S))$ & 7.42 & 5.93 \\
\hline 2008 ( $)$ & &
\end{tabular}

NB: The 2008 data were truncated at 140 metre. 


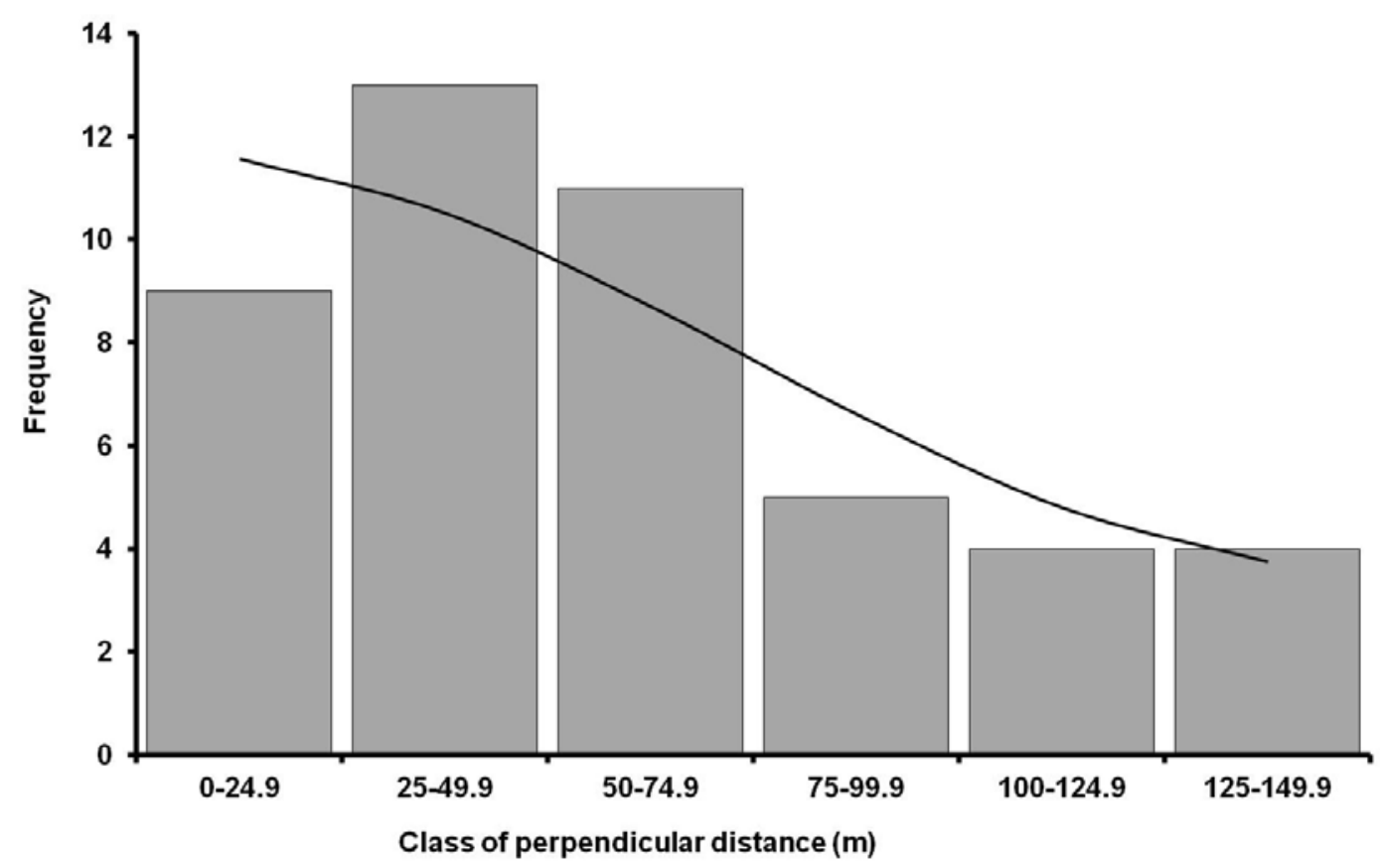

Figure 3. Histogram of perpendicular distances for the direct ground count of elephants in 2007. The fitted probability density curve is also shown

\subsection{Dung Counts}

Each dung count covered a total transect length of $54 \mathrm{~km}$. In 2007 the team recorded 2579 dung-piles (Table 2). The dung-pile population estimate was $1,828,800$ (95\% confidence interval: $1,381,000-2,421,900)$ or 1864.3 dungpiles. $\mathrm{km}^{-2}$ (95\% confidence interval: $\left.1407.7-2468.8\right)$. The CV was $14.1 \%$. The histogram of perpendicular distances (Figure 4) showed a good shoulder at the centre-line and a smooth detection curve.

In 2008 the team recorded 3819 dung-piles on the same transects (Table 2). The dung-pile population estimate was 2,230,400 (95\% confidence interval: 1,537,800-3,234,800) or 2274 dungpiles.km ${ }^{-2}(95 \%$ confidence interval: 1568-3298). The CV was $18.7 \%$. The observed frequencies and the fitted detection curve were similar to the previous year, but the higher $\chi^{2}$ value indicated that the fit was not as good (Table 2).

While the 2008 count represented a $22 \%$ increase compared to 2007 , in contrast to the direct counts which suggested a decrease, the difference was not significant $(d=0.82, \mathrm{NS})$. 
Table 2. Estimates of elephant dung abundance in two consecutive years in Nazinga Game ranch. The data were collected using the line transect method (Buckland et al., 1993; Thomas et al., 2003, 2010)

\begin{tabular}{lll}
\hline Parameter & $\begin{array}{l}\text { Dung population } \\
2007\end{array}$ & $\begin{array}{l}\text { Dung population } \\
2008\end{array}$ \\
\hline Number of observations $(n)$ & 2579 & 3819 \\
Estimator & Half-normal/Cosine & Half-normal/Cosine \\
Number of parameters used in the estimate & 4 & 3 \\
$f(O)$ & 0.07881 & 0.06490 \\
$\operatorname{var}[f(O)]$ & $0.33551 \times 10^{-5}$ & $0.12522 \times 10^{-5}$ \\
Effective strip width $w$ (in metre) & 12.69 & 15.41 \\
Densityestimate per km ${ }^{2}(D)$ & 1864.30 & 2273.6 \\
Var $(D)$ & 69000.78 & 180854.57 \\
$95 \%$ Upper confidence limit & 2468.8 & 3297.5 \\
$95 \%$ Lower confidence limit & 1407.7 & 1567.6 \\
$\% \mathrm{CV}$ & 14.09 & 18.70 \\
Population estimate $(N)$ & 1828800 & 2230400 \\
$95 \%$ Upper confidence limit & 2421900 & 3234800 \\
$95 \%$ Lower confidence limit & 1381000 & 1537800 \\
$X^{2}$ & 18.73 & 67.64 \\
$p$ & 0.539 & 0.000 \\
$d f$ & 20 & 21 \\
\hline
\end{tabular}

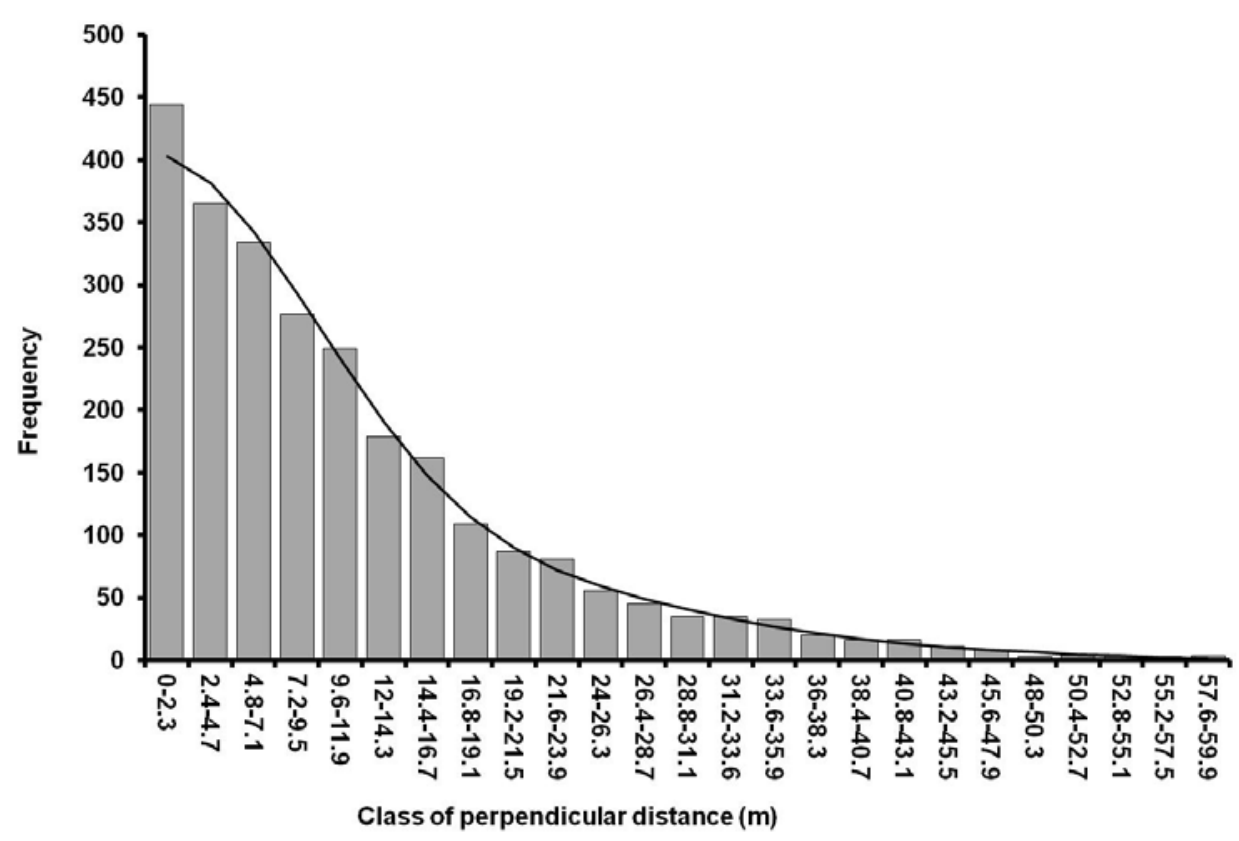

Figure 4. Histogram of perpendicular distances for the elephant dung count; the fitted probability density curve is also shown 


\subsection{Power Calculation}

With a $10 \%$ annual decrease in elephants, after 5 years direct counts would have a $22 \%$ probability of detecting a significant change in population size (Figure 5). In contrast, dung counts would have a $50 \%$ probability of detecting a significant change after 5 years. Direct ground counts would require 10 years of consecutive counts to have $80 \%$ power to detect a significant change (by convention $80 \%$ power is usually taken as the standard) whereas dung counts would exceed $80 \%$ by year 7 .

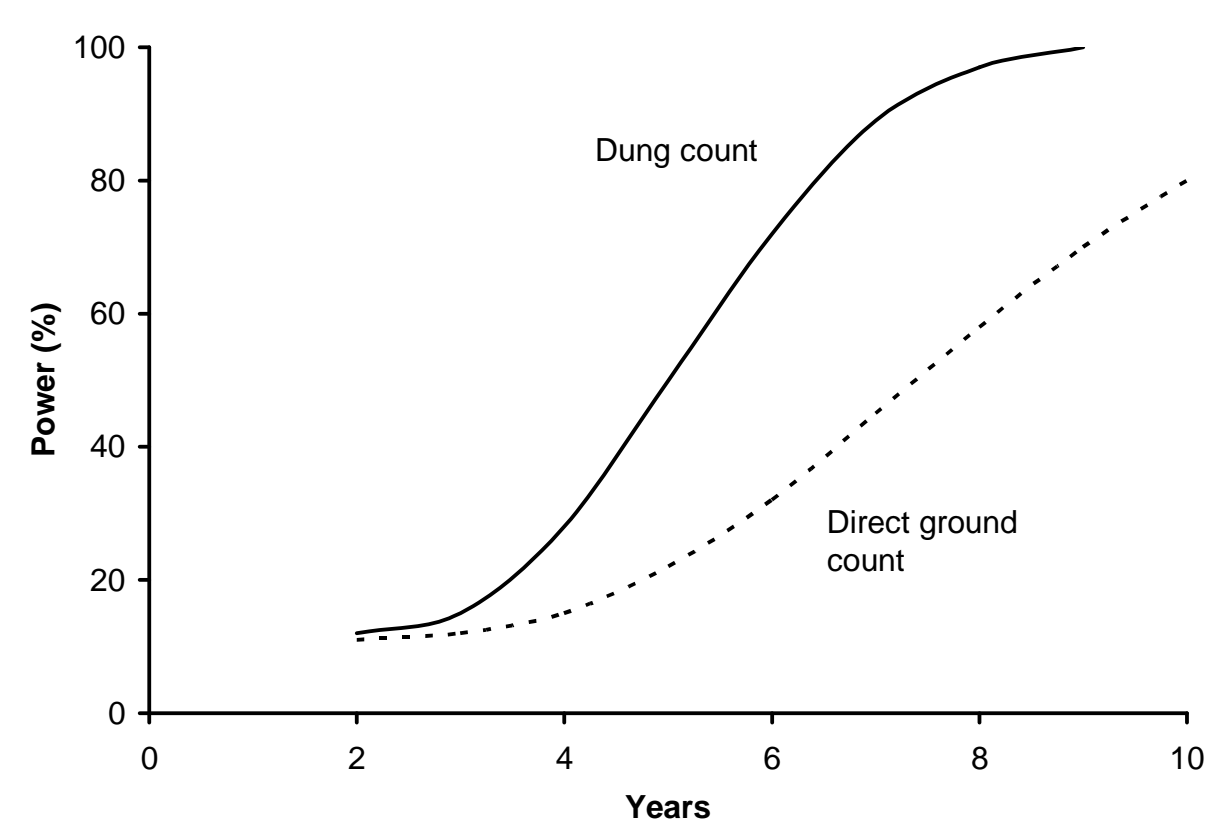

Figure 5. Comparison of power curves for direct and dung counts (each curve shows the power to detect an exponential decrease in numbers with a series of annual counts)

\section{Discussion}

The dung counts were more precise, since they had smaller CVs (Norton-Griffith, 1978; Buckland et al., 1993, 2001), than the direct counts. Therefore there was a higher probability of detecting a change in numbers using dung counts. In other words, greater statistical power was achieved with dung counts. Furthermore, the dung counts were far more efficient, since the smaller CVs were obtained with transects that totaled $54 \mathrm{~km}$ compared to $680.2 \mathrm{~km}$ for the direct ground counts. From the perspective of monitoring trends in elephant populations, dung counts are superior to direct ground counts.

However the dung count method rests upon the assumption that $c$ (in Equation 2) is constant from year to year. Dung decay rates vary with season and habitat type (Barnes, 1982; Laing et al., 2003). Rainfall affects the quality of the vegetation, and that affects the digestive processes and therefore the rate of defecation (Barnes, 1982). Rainfall also accelerates the rate of dung decay (Barnes, Asamoah-Boateng, Naada-Majam, \& Agyei-Ohemeng, 1997). Thus rainfall is the most important factor to affect the value of $c$. During the two years there were no evident change in habitat and so dung production rates were assumed constant. By executing our surveys at the same point in each year (in April, the late dry season) we assume that we eliminated any significant variation in dung decay rate. However, this assumption must be tested. An alternative hypothesis, which should also be tested, is that at the peak of the dry season $c$ is a function of accumulated temperature and accumulated rainfall since a fixed date, either $1^{\text {st }}$ January or the end of the previous wet season.

The variation in Nazinga elephant population estimates over the years is partly due to the movements of elephants in and out of the area which is linked by corridors to the Kaboré-Tambi NP (formerly Po NP) and the Nazinon valley to the northwest, and to the Sissili valley and Ghana to the south. It is also a consequence of the plethora of methods that has obscured any real trends. Consequently there is not a series of accurate estimates using the same method from which the trend can be estimated. The direct counts on the ground were planned to standardize the annual counts so as to provide an objective measure of trend from 1982. However, this method is 
inefficient and inaccurate, and it gives inconsistent results. For example, in 2007 the direct count estimated 2518 elephants for the RGN, the highest estimate ever recorded. The following year the same team walking exactly the same transects estimated less than half that number. In both years the counts failed to achieve the minimum number of observations required for a reasonable estimate (Buckland et al., 1993; Jachmann, 2001), despite covering $680 \mathrm{~km}$ of transect in each year.

Furthermore, in both years fewer elephants were seen close to the centre-line than in the 25-49 metre class (Figure 3). This contravenes one of the most important assumptions of line transect method: that all animals on the transect center line are observed with certainty (Buckland et al., 1993, 2001). This problem is due to elephants detecting the approach of the surveyors and moving away from the line of march before they were seen. The consequence of both the small number of sightings and the lack of a clear shoulder for the detection curve is an estimate lacking both accuracy and precision.

There is an additional problem common to line transect surveys of animals: the perpendicular distance was not measured directly. Rather, the animal-to-observer distance (or radial distance) was measured and then the perpendicular distance was later calculated by simple geometry. The detection function for the animal-to-observer distance gives a biased estimate of the probability density function on which the distance estimate depends (Buckland, Plumptre, Thomas, \& Rexstad, 2010). Therefore any estimate of elephant abundance produced by these direct counts is likely to be inaccurate (Buckland et al., 2010).

The direct ground counts required a huge sampling effort but gave a poor return: 0.05 groups recorded per $\mathrm{km}$ of transect for the 2007 and 2008 counts combined. In contrast, the encounter rate for the dung counts was orders of magnitude higher: 59.24 dung-piles per $\mathrm{km}$ of transect for the two counts combined. The histogram of perpendicular distances (Figure 4) is an excellent example of a visibility curve showing how the probability of detection decreases with distance from the transect center line. Consequently the estimate of dung-pile abundance is likely to be accurate.

The direct counts provided an instantaneous picture of the distribution of elephants across the study area. Consequently there was great variation between transects, with most transects recording no elephants at all. In addition, the elephant groups varied in size. These factors increased the variance of the direct estimate. In contrast, dung is more evenly distributed than an instantaneous snapshot of the animals, and the variation between transects is low (Jachmann, 1991). Consequently the CVs of the dung counts (14.1\% and $18.7 \%$ in 2007 and 2008 respectively) were considerably smaller than those of the direct counts ( $27.5 \%$ and $42.0 \%$ respectively). Therefore, the dung counts were considerably more precise and conferred greater statistical power to detect changes in elephant abundance.

Ouédraogo, Delvingt, Doucet, Vermeulen, and Bouché (2009) also recognized the problems of direct ground counts and tested a total ground count of elephants in the same Nazinga study area. Blocks were searched while walking along reconnaissance transects and signs of elephants were followed up until the elephants were sighted. This method may work well when there is only a small number of elephant groups and the study area is small, but is likely to become increasing inaccurate with larger populations and with an extensive area to cover (Ouédraogo et al., 2009). Total ground counts have also been used in India but need to be carefully controlled to avoid double-counting some groups and missing others (Lahiri-Choundhury, 1991). Whereas total counts from the air may give accurate estimates, total counts by observers on foot are open to too many potential biases for regular monitoring programmes.

Dung counts also have potential sources of errors such as observer efficiency, difficulty of distinguishing whether adjacent dung-piles represent a single defaecation or two or more defaecations, and determining whether a dung-pile has decayed to the point where it should not be recorded (Barnes, 1993; Hedges \& Lawson, 2006). Transforming dung density into elephant density results in wider confidence limits because the standard error (SE) of defaecation and of decay each contribute to the standard error (SE) of elephants numbers (Barnes, 1993). But this is an unnecessary complication if one is concerned only with evaluating trends in the elephant population. Here we advocate using dung density as the index of elephant abundance and an index of population change. There is no need to go through the costly exercise of estimating dung decay rates and defaecation rates, because it is not necessary to convert dung density into animal density when monitoring the same area year after year. As long as dung counts are conducted at the same time of year so that conditions are standardized-for example, the end of the dry season-then estimates of dung density will provide valid estimates of trend.

This raises the fundamental question: what is the purpose of counting animals in a protected area? A manager may like to know how many individuals of a particular species are in his domain. But in most cases the trend is more important than the actual number, and to evaluate the trend one needs precise estimates. For this purpose an 
index of population size that is precise is more useful than an estimate of animal numbers (Jachmann, 2001). Direct ground counts provide estimates with lower precision that dung count. Hence, dung counts are most likely to give the required information on trends. Furthermore, aerial sample counts are also unlikely to give useful data on trends, especially in the West African context where dung counts give estimates that are more precise than those from aerial sample surveys (Barnes, 2002). Even when animals are at low density, there will always be plenty of dung in the dry season because the rate of dung decay is zero while animals will continue to defecate (Jachmann \& Bell, 1979, 1984).

We recommend that for monitoring elephant trends at Nazinga, a dung count be conducted at the same time each year: the peak of the dry season. Once one has established the transect design, the same transects can be sampled year after year. The methods of data collection are simple and wildlife staff can be easily trained to do this work. The dung counting methods outlined in this paper are simple and practical, and will allow the wildlife manager to monitor the abundance and distribution of all large herbivore populations, not just elephants, year after year.

With growing concern about the decline of wildlife populations in protected areas (Brashares, Arcese, \& Sam, 2001; Craigie et al., 2010), it will become increasingly important to evaluate trends. As populations diminish, the relative advantages of dung counts over other methods will increase (Barnes, 2002). Therefore we recommend that wildlife biologists should increasingly immerse themselves in dung. We recommend that monitoring programmes follow the protocol developed by Hedges and Lawson (2006) for dung counts. These arguments apply to elephants but may well be applied to all herbivores at Nazinga.

Resources for wildlife studies are scarce yet the needs to evaluate trends are urgent because of expanding human pressures around protected areas like Nazinga (Hema et al., 2010). Dung counts can be applied to all savannas, bushlands and woodlands elsewhere across the continent. They may apply not just to protected areas of modest size but also to large ecosystems where estimates of trends for all herbivores are needed (Caro, 2008). Furthermore, where poaching has been intense, and animals are shy, dung counts will give an estimate of trend better than the direct ground count. However, many wildlife managers are skeptical about the validity of dung counts in general. We suggest that the validity of dung counts for monitoring large herbivores in open country should be verified at a large site that already has a well-established monitoring program.

\section{Acknowledgements}

Field work was financed by the Nazinga Game Ranch as part of its Ecological Monitoring Program; we benefited from additional supports from the consortium of Wild Foundation in USA, Save the Elephants in Kenya and the Environment \& Development Group in UK.

The late M. Adama Ouédraogo, Director of the Ranch during the period of the study, gave us permission to work at Nazinga. We are grateful to the Directeur de la Faune et des Chasses M. Urbain Belemsobgo who made the study possible. We thank all field assistants especially M. Banzourou Niagabaré, M. Néti Naman, M. Tinsgnimi Dialla, M. Ousmane Badini, M. Boukaré Ouédraogo, M. Dominique Zida, M. Boureima Kaboré and M. Misson Zida, for their support.

\section{References}

Barnes, R. F. W. (1982). Elephant feeding behaviour in Ruaha National Park. African Journal of Ecology, 20, 123-136. http://dx.doi.org/10.1111/j.1365-2028.1982.tb00282.x

Barnes, R. F. W. (1993). Indirect methods for counting elephants in forest. Pachyderm, 16, 24-30.

Barnes, R. F. W. (2001). How reliable are dung counts for estimating elephant numbers? African Journal of Ecology, 39, 1-9.

Barnes, R. F. W. (2002). The problem of precision and trend detection posed by small elephant populations in West Africa. African Journal of Ecology, 40, 179-185. http://dx.doi.org/10.1046/j.1365-2028.2002.00376.x

Barnes, R. F. W., \& Jensen, K. L. (1987). How to count elephants in forests. African Elephant \& Rhino Specialist Group Technical Bulletin, 1, 1-6.

Barnes, R. F. W., Asamoah-Boateng, B., Naada-Majam, J., \& Agyei-Ohemeng, J. (1997). Rainfall and the population dynamics of elephant dung-piles in the forests of southern Ghana. African Journal of Ecology, 35, 39-52. http://dx.doi.org/10.1111/j.1365-2028.1997.061-89061.x

Bouché, P., Lejeune, P., \& Vermeulen, C. (2012). How to count elephants in West African savannahs? Synthesis and comparison of main game count methods. Biotechnol. Agron. Soc. Environ., 16(1), 77-91. 
Bouché, P., Lungren, G. C., \& Hien, B. (2004). Recensement aérien total de la faune dans l'écosystème naturel Po-Nazinga-Sissili (PONASI). Unpublished report, CITES MIKE, Ouagadougou, Burkina Faso.

Brashares, J. S., Arcese, P., \& Sam, M. K. (2001). Human demography and reserve size predict wildlife extinction in West Africa. Proceedings of the Royal Society of London, B268, 2473-2478. http://dx.doi.org/10.1098/rspb.2001.1815

Buckland, S. T., Anderson, D. R., Burnham, K. P., \& Laake, J. L. (1993). Distance sampling: Estimating Abundance of Biological Populations. London \& New York: Chapman \& Hall.

Buckland, S. T., Anderson, D. R., Burnham, K. P., Laake, J. L., Borchers, D. L., \& Thomas, L. (2001). Introduction to distance sampling: Estimating abundance of biological populations. New York: Oxford University Press.

Buckland, S. T., Plumptre, A. J., Thomas, L., \& Rexstad, A. (2010). Line transect sampling of primates: can animal-to-observer distance methods work? International Journal of Primatology, 31, 485-499. http://dx.doi.org/10.1007/s10764-010-9408-4

Caro, T. (2008). Decline of large mammals on the Katavi-Rukwa ecosystem of western Tanzania. African Zoology, 43, 99-116. http://dx.doi.org/10.3377/1562-7020(2008)43[99:DOLMIT]2.0.CO;2

Cornelis, D. (2000). Analyse du monitoring écologique et cynégétique des populations d'ongulés au Ranch de Gibier de Nazinga. Mémoire de DEA; Faculté des Sciences Agronomiques de Gembloux.

Craigie, I. D., Baillie, E. M., Balmford, A., Carbonne, C., Collen, B., Green, R. E., \& Hutton, J. M. (2010). Large mammal population declines in Africa's protected areas. Biological Conservation, 143, 2221-2228. http://dx.doi.org/10.1016/j.biocon.2010.06.007

Damiba, T. E., \& Ables, E. D. (1994). Population characteristics and impacts on woody vegetation of elephants on Nazinga Game Ranch, Burkina Faso. Pachyderm, 18, 46-53.

Gerrodette, T. (1987). A power analysis for detecting trends. Ecology, 68(5), 1364-1372. http://dx.doi.org/10.2307/1939220

Gerrodette, T. (1993). TRENDS: software for a power analysis of linear regression. Wildl. Soc. Bull., 21, 515-516.

Guinko, S. (1985). La végétation et la flore du Burkina Faso. Ministère de l'Environnement et du Tourisme, Direction de l'Aménagement Forestier et du Reboisement, Ouagadougou, Burkina Faso.

Hedges, S., \& Lawson, D. (2006). Monitoring the illegal killing of elephants: Dung survey standards for the MIKE programme. Unpublished report, CITES/MIKE programme, Nairobi, Kenya.

Hema, M. E., Barnes, R. F. W., \& Guenda, W. (2010). Distribution of savannah elephants (Loxodonta Africana africana Blumenbach 1797) within Nazinga game ranch, Southern Burkina Faso. African Journal of Ecology, 49, 141-149. http://dx.doi.org/10.1111/j.1365-2028.2010.01239.x

Hema, M. E., Ouédraogo, A., Belemsobgo, U., \& Guenda, W. (2007). Recensements pédestres des grands mammifères diurnes au Ranch de Gibier de Nazinga; 2004-2006. Unpublished report, Nazinga Game Ranch, Burkina Faso.

Jachmann, H. (1988). Numbers, distribution and movements of the Nazinga elephant. Pachyderm, 10, 16-21.

Jachmann, H. (1991). Evaluation of four survey methods for estimating elephant densities. African Journal of Ecology, 29, 188-195. http://dx.doi.org/10.1111/j.1365-2028.1991.tb01001.x

Jachmann, H. (2001). Estimating abundance of African wildlife: an aid to adaptive management. Boston: Kluwer. http://dx.doi.org/10.1007/978-1-4615-1381-0

Jachmann, H., \& Bell, R. H. V. (1979). The assessment of elephant numbers and occupance by means of dropping counts in the Kasungu national park, Malawi. African Journal of Ecology, 17, 231-239. http://dx.doi.org/10.1111/j.1365-2028.1979.tb00259.x

Jachmann, H., \& Bell, R. H. V. (1984). The use of elephant droppings in assessing numbers, occupance and age structure: a refinement of the method. African Journal of Ecology, 22, 127-141. http://dx.doi.org/10.1111/j.1365-2028.1984.tb00686.x

Johnson, C. N., \& Jarman, P. J. (1987). Macropod Studies at Wallaby Creek VI.A validation of the Use of Dung-Pellet Counts for Measuring Absolute Densities of Populations of Macropodids. Aust. Wildl. Res., 14, 139-145. http://dx.doi.org/10.1071/WR9870139 
Karels, T. J., Koppel, L., \& Hik, D. S. (2004). Fecal Pellet Counts as a Technique for Monitoring an Alpine-Dwelling Social Rodent, the Hoary Marmot (Marmota caligata). Arctic, Antarctic, and Alpine Research, 36(4), 490-494. http://dx.doi.org/10.1657/1523-0430(2004)036[0490:FPCAAT]2.0.CO;2

Lahiri-Choudhury, D. K. (1991). Direct counts of elephants in north-east India. In: Censusing elephants in forests: Proceedings of an international workshop, southern India 2-10 January 1991.

Laing, S. E., Buckland, S. T., Burn, R. W., Lambie, D., \& Amphleett, A. (2003). Dung and nest surveys: Estimating decay rates. Journal of Applied Ecology, 40, 1102-1111. http://dx.doi.org/10.1111/j.1365-2664.2003.00861.x

Neff, D. J. (1968). The pellet-group count Technique for big game Trend, Census, and Distribution: A Review. Journal of Wildlife Management, 32(3), 597-614. http://dx.doi.org/10.2307/3798941

Norton-Griffiths, M. (1978). Counting animals. African Wildlife Leadership Foundation, Nairobi.

O’Donoghue, M. (1985). Ground census of large mammals at the Nazinga game ranch Project. Unpublished report, Nazinga Game Ranch, Burkina Faso.

Ouédraogo, M., Delvingt, W., Doucet, J. L., Vermeulen, C., \& Bouché, P. (2009). Estimation des effectifs des populations d'éléphants par la méthode d'inventaire pédestre total au Ranch de Gibier de Nazinga (Burkina Faso). Pachyderm, 45, 57-66.

Spinage, C. (1984). Analyse des données de climat de Pô et de Léo en référence à Nazinga. Unpublished report, FAO Ouagadougou, Burkina Faso.

Taylor, B. L., \& Gerrodette, T. (1993). The uses of statistical power in conservation biology: the vaquita and the

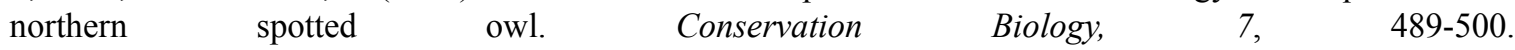
http://dx.doi.org/10.1046/j.1523-1739.1993.07030489.x

Thomas, L., Buckland, S. T., Rexstad, E. A., Laake, J. L., Strindberg, S., Hedley, S. L., ... Burnham, K. P. (2010). Distance software: design and analysis of distance sampling surveys for estimating population size. Journal of Applied Ecology, 47, 5-14. http://dx.doi.org/10.1111/j.1365-2664.2009.01737.x

Thomas, L., Laake J. L., Strindberg, S., Marques, F. F. C., Buckland, S. T., Borchers, D. L., ... Bishop, J. R. B. (2003). DISTANCE 4.1 Release 2. Research Unit for Wildlife Population Assessment, University of St Andrews, UK. Retrieved from http://www.ruwpa.st-and.ac.uk/distance/ 